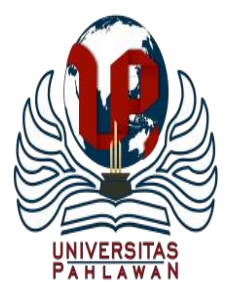

Jurnal Basicedu Volume 4 Nomor 4 Tahun 2020 Halaman 1408 - 1422

JURNAL BASICEDU

Research \& Learning in Elementary Education

https://jbasic.org/index.php/basicedu

\title{
Penerapan Sistem Informasi Manajemen Pendidikan dalam Proses Pembelajaran
}

\author{
Siti Hajar Loilatu ${ }^{1}$, M. Rusdi ${ }^{2}$, Musyawir ${ }^{3}$
}

Fakultas Keguruan dan Ilmu Pendidikan, Universitas Iqra Buru, Maluku, Indonesia

E-mail : azhaloilatu@gmail.com ${ }^{1}$ rusdigallarang92@gmail.com ${ }^{2}$ musyawir.rs@gmail.com ${ }^{3}$

\begin{abstract}
Abstrak
Penelitian ini bertujuan untuk mengetahui penerapan Sistem Informasi Manajemen di SMP Negeri 9 Kabupaten Buru. Penelitian ini termasuk jenis penelitian kualitatif deskriptif. Teknik pengumpulan data yang digunakan dalam penelitian ini adalah teknik observasi, wawancara, dan dokumentasi. Tahap analisis data dalam penelitian ini adalah pengumpulan data, reduksi data, penyajian data, dan penarikan simpulan atau verifikasi. Hasil penelitian ini menunjukkan bahwa (1) penerapan sistem informasi manajemen sangat penting di lembaga pendidikan khususnya di SMP Negeri 9 Kabupaten Buru, dengan menggunakan aplikasi pengolah data yaitu Data Pokok Pendidik (Dapodik) dan teknologi informasi dalam mendukung proses pembelajaran memberikan layanan pendidikan dengan menfasilitasi praktik pembelajaran dengan menggunakan atau memanfaatkan infrastkruktur teknologi, seperti fasilitas belajar dengan memadukan komputer; dan (2) pelaksanaan proses pembelajaran di SMP Negeri 9 Kabupaten Buru berdasarkan hasil penelitian yaitu sebelum melaksanakan proses pembelajaran harus melalui tiga tahapan penting, yaitu tahap perencanaan, tahap pelaksanaan, dan tahap evaluasi.
\end{abstract}

Kata kunci : penerapan, sistem informasi manajemen, pembelajaran

Abstract

This study aims to determine the application of Management Information Systems in SMP Negeri 9 Buru Regency. This research is a descriptive qualitative research. Data collection techniques used in this research are observation, interview, documentation techniques. The data analysis stage in this study was data collection, data reduction, data presentation, and drawing conclusions or verification. The results of this study indicate that (1) the application of management information systems is very important in educational institutions, especially in SMP Negeri 9 Buru Regency, by using data processing applications, namely Primary Data Educators (Dapodik) and information technology in supporting the learning process of providing educational services by facilitating learning practices. by using or utilizing technological infrastructure, such as learning facilities by integrating computers; and (2) the implementation of the learning process at SMP Negeri 9 Buru Regency based on the research results, namely, before carrying out the learning process, it must go through three important stages, namely, first, the planning stage, second, the implementation stage, and third, the evaluation stage.

Keywords: application, management information systems, learning

Copyright (c) 2020 Siti Hajar Loilatu, M.Rusdi, Musyawir

$\triangle$ Corresponding author

Address : Universitas Iqra Buru

Email : musyawir.rs@gmail.com

ISSN 2580-3735 (Media Cetak)

Phone : +6282347727437

ISSN 2580-1147 (Media Online)

DOI: https://doi.org/10.31004/basicedu.v4i4.520 
1409 Penerapan Sistem Informasi Manajemen Pendidikan dalam Proses Pembelajaran - Siti Hajar Loilatu, M.Rusdi, Musyawir

DOI: https://doi.org/10.31004/basicedu.v4i4.520

\section{PENDAHULUAN}

Penerapan sistem informasi manajemen yang berbasis kompetensi menjadi kebutuhan yang mutlak dan dapat memberikan keunggulan kompetitif sehingga mendapat prioritas yang tinggi. Pengelolaan atau manajemen yang baik dalam suatu lembaga pendidikan menjadi hal yang mutlak bagi keberlangsungan hidup lembaga tersebut. Salah satu hal penting yang dapat mempertahankan bahkan mengembangkan sebuah lembaga pendidikan adalah pengelolaan sistem informasi secara tepat (Helmawati, 2015).

Pada umumnya, apabila seseorang membicarakan sistem informasi manajemen, yang tergambar adalah suatu sistem yang diciptakan untuk melaksanakan pengolahan data yang akan dimanfaatkan suatu organisasi. Kini, kalau seseorang mendengar istilah sistem informasi manajemen, biasa juga mereka membayangkan suatu sistem komputer. Inti pengertian sistem informasi manajemen konvensional tentu saja terdapat dalam pekerjaan-pekerjaan sistematis seperti pencatatan agenda, kearsipan, komunikasi diantara manajer-manajer organisasi, penyajian informasi untuk pengambilan keputusan, dan lainsebagainya (Tata Sutabri, 2013).

Pada prinsipnya dalam pengajaran, perumusan tujuan adalah yang utama dan setiap proses pengajaran senantiasa diarahkan untuk mencapai tujuan yang telah ditetapkan. Untuk itu, proses pengajaran harus direncanakan. Ketercapaian tujuan dapat dikontrol sejauh mana tujuan itu telah tercapai. Pembelajaran adalah suatu kombinasi yang tersusun meliputi unsurunsur manusiawi, material, fasilitas, perlengkapan, dan prosedur yang saling mempengaruhi untuk mencapai tujuan pembelajaran. Untuk menjamin agar informasi dapat mengalir dengan baik, dalam sebuah lembaga pendidikan perlu dikembangkan sebuah sistem informasi manajemen yang melibatkan komponen internal-eksternal lembaga pendidikan untuk menjamin alur informasi yang efektif dan berkualitas, yaitu tersedianya teknologi informasi yang didukung oleh sumber daya manusia yang mampu mengoperasikannya.

Dengan adanya sistem informasi manajemen, dapat menunjang kelancaran aktivitas lembaga pendidikan, khususnya dalam proses pembelajaran antara pendidik dan peserta didik untuk mencapai tujuan pendidikan yang diinginkan. Berdasarkan observasi pendahuluan di SMPN 9 Kabupaten Buru ini sebagai lembaga pendidikan formal yang juga mempunyai sistem informasi manajemen, dalam rangka menyikapi segala perubahan dan perkembangan yang terjadi di lingkungannya, khususnya dibidang pendidikan serta perannya dalam proses pembelajaran. Salah satu alasan diterapkan sistem informasi manajemenya itu untuk memperlancar proses belajar mengajar di sekolah, karena dilihat dari kondisi penyediaan bahan ajar atau buku pelajaran sangatlah kurang, maka pendidik di SMPN 9 Kabupaten Buru memanfaatkan teknologi informasi yang ada untuk mendapat bahan ajar dengan cara mengunduh di internet guna memperlancar proses belajar mengajar.

Berdasarkan uraian latar belakang tersebut, maka penelitian ini memiliki rumusan masalah, yakni bagaimanakah penerapan Sistem Informasi Manajemen di SMP N 9 Kabupaten Buru, bagaimanakah proses pembelajaran di SMP N 9 Kabupaten Buru, dan faktor-faktor apakah yang 
1410 Penerapan Sistem Informasi Manajemen Pendidikan dalam Proses Pembelajaran - Siti Hajar Loilatu, M.Rusdi, Musyawir

DOI: https://doi.org/10.31004/basicedu.v4i4.520

menghambat dan mendukung tentang penerapan sistem informasi manajemen dalam kelancaran proses pembelajaran di SMP N 9 Kabupaten Buru.

Manfaat penelitian ini, yaitu meningkatkan minat dan motivasi belajar peserta didik serta mendorong peserta didik berperan aktif dalam proses pembelajaran sehingga peserta didik mendapat hasil belajar yang maksimal khususnya dalam bidang teknologi yang semakin berkembang dan meningkatkan kinerja pendidik dan pegawai, sehingga dapat berkembang secara profesional dalam meningkatkan pelayanan terhadap peserta didik. Selain itu, penelitian ini nantinya menjadi rekomendasi kepada pihak sekolah di SMP Negeri 9 Kabupaten Buru terkait dengan pentingnya penerapan sistem informasi manajemen dalam kelancaran proses pembelajaran.

Sistem informasi manajemen merupakan sebuah sistem informasi yang selain melakukan pengolahan transaksi yang sangat berguna bagi kepentingan organisasi, juga banyak memberikan dukungan informasi dan pengolahan untuk fungsi manajemen dalam pengambilan keputusan (Siswanto, 2012). Menurut Ais Zakiyudin (2012) dalam bukunya bahwa, sistem informasi manajemen adalah suatu sistem informasi manajemen menggambarkan ketersediaan suatu rangkaian data yang cukup lengkap yang disimpan agar dapat menyediakan informasi untuk mendukung operasional, manajemen, dan pembuatan keputusan dalam suatu organisasi.

Berdasarkan definisi para ahli, maka dapat disimpulkan bahwa,sistem informasi manajemen adalah suatu sistem yang dirancang untuk menyediakan informasi guna mendukung pengambilan kepetusan pada kegiatan manajemen dalam suatu organisasi. Tujuan dibentuknya sistem informasi manajemen adalah supaya organisasi memiliki suatu sistem yang dapat diandalkan dalam mengolah data menjadi informasi yang bermanfaat dalam pembuatan keputusan manajemen, baik yang menyangkut keputusankeputusan rutin maupun keputusan-keputusan strategik. Dengan demikian Sistem Informasi Manajemen adalah suatu sistem yang menyediakan kepada pengelola organisasi data maupun informasi yang berkaitan dengan pelaksanaan tugas-tugas organisasi. (Wahyudi K. \&Subando, 2012).

Beberapa kegunaan/fungsi Sistem Informasi antara lain sebagai berikut:

a. Meningkatkan aksesibilitas data yang tersaji secara tepat waktu dan akurat bagi para pemakai, tanpa mengharuskan adanya perantara sistem informasi.

b. Menjamin tersediannya kualitas dan keterampilan dalam memanfaatkan sistem informasi secara kritis.

c. Mengembangkan proses perencanaan yang efektif.

d. Mengidentifikasi kebutuhan-kebutuhan akan keterampilan pendukung sistem informasi.

e. Menetapkan investasi yang akan diarahkan pada sistem informasi.

f. Mengantisipasi dan memahami konsekuensikonsekuensi ekonomis dari sistem informasi dan teknologi baru.

g. Memperbaiki produktivitas dalam aplikasi pengembangan dan pemeliharaan sistem.

h. Organisasi menggunakan sistem informasi untuk mengolah transaksi-transaksi, mengurangi biaya dan menghasilkan 
1411 Penerapan Sistem Informasi Manajemen Pendidikan dalam Proses Pembelajaran - Siti Hajar Loilatu, M.Rusdi, Musyawir

DOI: https://doi.org/10.31004/basicedu.v4i4.520

pendapatan sebagai salah satu produk atau pelayanan.

i. Bank menggunakan sistem informasi untuk mengolah cek-cek nasabah dan membuat berbagai laporan rekening koran dan transaksi yang terjadi.

j. Perusahaan menggunakan sistem informasi untuk mempertahankan persediaan pada tingkat paling rendah agar konsisten dengan dengan jenis barang yang tersedia.

k. Sitem informasi manajemen untuk pendukung pengambilan keputusan.

1. Sistem informasi manajemen berdasarkan aktivitas/kegiatan manajemen.

m. Sistem informasi untuk pengendalian operasional.

n. Sistem informasi untuk pengendalian manajemen.

o. Sistem informasi untuk perencanaan strategik.

p. Sistem informasi manajemen berdasarkan fungsi organisasi (Eti Rochaety).

Tujuan dari dibangunnya informasi berupa aplikasi sistem informasi pendidikan adalah:

a. Membantu seluruh bagian yang berperan di dunia pendidikan dengan memberikan informasi yang menyeluruh tentang pendidikan dari tingkat sekolah dasar hingga sekolah menengah umum atau yang setara dengannya.

b. Pertanggungjawaban publik yaitu dengan memberikan informasi secara transparan tentang kebijakan dan pemakaian sumber daya yang dialokasikan untuk dunia pendidikan. c. Memberi sarana agar seluruh bagian yang berperan dalam dunia pendidikan yang ada di Propinsi, Kota/Kabupaten agar dapat berperan aktif dalam usaha memajukan usaha pendidikan.

d. Meningkatkan pengetahuan pendidik dan peserta didik tentang dunia informatika serta manfaat yang dapat diambil melalui beberapa pelatihan.

e. Memberikan akses informasi yang mudah dan lengkap bagi pendidik dan peserta didik mengenai ilmu pengetahuan dan informasi pendidikan lainnya.

Maksud dilaksanakannya sistem informasi manajemen pendidikan adalah, sebagai pendukung kegiatan fungsi manajemen dalam rangka menunjang tercapainya sasaran dan fungsi-fungsi operasional dalam organisasi pendidikan.

Sistem informasi manajemen merupakan suatu badan yang memiliki bagian-bagian yang memiliki tugas-tugas tertentu. Bagian-bagian itu adalah pengumpulan data, penyimpanan data, pemroses data, dan pemrogram data (Made Pidarta, 2013). Dalam bagian-bagian terdapat seseorang koordinator yang bertugas mengkordinir pada semua bagian dan bertanggung jawab langsung pada manajemen puncak atau kepala sekolah.

Keamanan sistem informasi manajemen menjadi bagian yang sangat penting untuk menjamin keutuhan data dan kualitas informasi yang dihasilkan. Beberapa prosedur yang telah dirumuskan untuk melindungi data dan informasi, baik dari faktor kesengajaan maupun masalah 
1412 Penerapan Sistem Informasi Manajemen Pendidikan dalam Proses Pembelajaran - Siti Hajar Loilatu, M.Rusdi, Musyawir

DOI: https://doi.org/10.31004/basicedu.v4i4.520

teknis dan etika yang diperkirakan akan merusak, menghilangkan atau menghambat distribusi data dan informasi tersebut. Upaya yang dilakukan secara teknis untuk mengatasi hal tersebut yaitu dengan menyusun visi bersama guna melindungi dan mengamankan data dan informasi.

Pembelajaran sebagai perpaduan dari dua aktivitas, yaitu aktivitas mengajar dan aktivitas belajar. Aktivitas mengajar menyangkut peranan seorang pendidik dalam konteks mengupayakan terciptanya jalinan komunikasi harmonis atau interaksi edukatif antara mengajar dengan belajar. Jalinan komunikasi yang harmonis inilah yang menjadi indikator suatu aktivitas/proses pembelajaran itu berjalan dengan baik. Pembelajaran adalah totalitas aktivitas belajar mengajar yang diawali dengan perencanaan diakhiri dengan evaluasi (Salehuddin, 2012).

Pembelajaran adalah operasionalisasi dari kurikulum. Pembelajaran di sekolah terjadi apabila terdapat interaksi antara siswa dengan lingkungan belajar yang diatur oleh pendidik untuk mencapai tujuan pembelajaran (Nana Sudjana, 2014). Berdasarkan defenisi para ahli, dapat disimpulkan bahwa pembelajaran adalah interaksi peserta didik dengan pendidik dan sumber belajar pada suatu lingkungan belajar yang meliputi pendidik dan peserta didik yang saling bertukar informasi untuk mencapai tujuan pembelajaran.

\section{METODE}

Penelitian ini termasuk jenis penelitian kualitatif deskriptif. Disebut penelitian kualitatif, karna sumber data utama penelitian ini adalah berupa kata-kata dan tindakan dari orang-orang yang diamati atau diwawancarai (Moleong, 2013). a. Obsevasi

Secara umum observasi merupakan suatu teknik atau cara mengumpulkan data dengan mengadakan pengamatan terhadap suatu kegiatan. Teknik observasi adalah pengamatan yang dilakukan secara sengaja, sistematis mengenai fenomena social dengan gejala-gejala psikis yang kemudian yang dilakukan pencatatan (Joko Subagyo, 2012).

b. Wawancara

Wawancara adalah suatu cara pengumpulan data yang digunakan untuk memperoleh informasi langsung dari sumbernya. Wawancara dapat dipandang sebagai metode pengumpulan data dengan jalan tanya jawab sepihak yang dikerjakan secara sistematis dan berdasarkan kepada tujuan penelitian. Pada umumnya dua orang atau lebih, hadir secara fisik dalam proses tanya jawab (Winarno Surahkmad, 2013). Adapun wawancara yang digunakan adalah wawancara tak terstruktur yaitu wawancara yang memiliki informan terpilih disesuaikan dengan sifat-sifatnya yang khas. Dalam hal ini informan yang dipilih adalah para pengelola lembaga pendidikan yang bersangkutan meliputi kepala sekolah, wakasek, guru, dan kepala TU. Karena mereka dianggap memiliki pengetahuan dan mendalami situasi serta lebih mengetahui informasi yang diperlukan.

c. Dokumentasi

Dokumentasi adalah metode yang digunakan untuk memperoleh data langsung dari tempat penelitian meliputi buku yang relevan, peraturan-peraturan, laporan kegiatan, foto- 
1413 Penerapan Sistem Informasi Manajemen Pendidikan dalam Proses Pembelajaran - Siti Hajar Loilatu, M.Rusdi, Musyawir

DOI: https://doi.org/10.31004/basicedu.v4i4.520

foto, film dokumen, dan data yang relevan dengan penelitian.

Berkaitan dengan metode analisis data, Winarno Surachmad berpendapat bahwa, metode analisis data adalah usaha yang konkret untuk membuat data tersebut berbicara, sebab berapapun jumlah data dan tingginya nilai data yang terkumpul sebagai hasil dari pengumpulan data bila tidak disusun dan diolah secara sistematis niscaya data-data itu merupakan bahan-bahan yang membisu. Tahap analisis data dalam penelitian kualitatif secara umum dimulai sejak pengumpulan data, reduksi data, penyajian data, dan penarikan kesimpulan atau verifikasi.

Untuk menguji keabsahan data yang telah dikumpulkan, peneliti menggunakan tiga teknik pemeriksaan triangulasi. Pemeriksaan keabsahan data yang memanfaatkan sesuatu yang lain di luar untuk keperluan pengecekan atau sebagai pembanding terhadap data tersebut.

Triangulasi dalam penguji kreabilitas ini diartikan sebagai data dari berbagai sumber, dengan cara, dan berbagai waktu. Dengan demikian terdapat triangulasi sumber, teknik, dan waktu. Dan disini penulis memilih triangulasi sumber, triangulasi ini juga disebut sebagai teknik penguji yang memanfaatkan penggunaan sumber yaitu membandingkan dan mengecek terhadap data yang diperoleh dengan cara membandingkan apa yang dikatakan orang di depan umum dengan dengan apa yang dikatakan secara pribadi, membandingkan hasil wawancara dengan ini suatu dokumen yang saling berkaitan, mengadakan perbincangan dengan banyak pihak untuk mencapai pemahaman tentang suatu atau berbagai hal.

\section{HASIL DAN PEMBAHASAN}

\section{Penerapan Sistem Informasi Manajemen di SMP Negeri 9 Kabupaten Buru}

Sistem informasi manajemen merupakan, bagian dari ilmu manajemen. Semua fungsi manajemen baik itu perencanaan (planning), pengorganisasian (organizing), pemimpin (leading/actuating), dan pengendalian (contrilling) diperlukan untuk keberhasilan kegiatan dalam suatu organisasi, termasuk dalam bidang pendidikan.

Keberhasilan saat menjalankan fungsi manajemen tersebut salah satunya ditunjang oleh sistem informasi yang mampu menyediakan informasi yang dibutuhkan para pengolah (pemimpin lembaga tersebut). Menurut, Bapak La Pou, S.Pd. selaku kepala sekolah menyatakan bahwa:

"Sistem informasi manajemen adalah suatu sistem yang berorientasi kepada sistem informasi yang mementingkan keakrutan data dan ketepatan sasaran dalam memperoleh berbagai data dan informasi yang dibutuhkan sekolah. Informasi yang dibutuhkan seperti sarana prasarana, pembiayaan, pengelolaan, kompotensi lulusan, penilaian, standar isi, pendidik dan tenaga kependidikan. Adapun sistem pengelola data yang digunakan disini yaitu DAPODIK yang meliputi data pendidik, tenaga kependidikan, data siswa, data sarana dan prasarana, dan sebagainya yang secara cepat dan valid yang disampaikan kepada instansi seperti Dinas Pendidikan Kabupaten/Kota, maupun ke Kementrian Nasional”.

Dapodik adalah, suatu sistem pendataan dan pengelolaan data-data pendidikan yang bersifat mikro secara daring dan real time. Terdapat jenis 
1414 Penerapan Sistem Informasi Manajemen Pendidikan dalam Proses Pembelajaran - Siti Hajar Loilatu, M.Rusdi, Musyawir

DOI: https://doi.org/10.31004/basicedu.v4i4.520

data utama yang dikelola pada sistem dapodik, meliputi data sekolah, data siswa, data pendidik, data karyawan, dan staf sekolah. Dapodik bertujuan untuk mewujudkan basis data sehingga dapat tercipta tata kelola data pedidikan yang terpadu dan menghasilkan data yang representatif untuk memenuhi kebutuhan kementrian dan pemangku kepentingan lainnya. Selanjutnya tujuan berikutnya adalah untuk mendukung peningkatan efesiensi, efektif, dan sinergi kegiatan pengumpulan data pokok yang terintegrasi dalam satu sistem pendataan.

Untuk melaksanakan sistem informasi manajemen di SMP Negeri 9 Kabupaten Buru mempunyai tiga bagian untuk mengolah data yaitu, bagian pengumpulan data, bagian pengolahan data, dan bagian penyimpanan data.

1. Bagian Pengumpulan Data

Data yang dikumpulkan berupa data internal dan data eksternal. Data internal merupakan data yang berasal dari dalam organisasi sedangkan data eksternal merupakan data yang berasal dari luar organisasi akan tetapi masi terdapat hubungan dengan perkembangan organisasi. Data internal dapat diperoleh dari semua unit kerja dalam organisasi yaitu dari wakasek, meliputi wakasek bagian pengajaran, kesiswaan, sarana prasarana, dan humas. Ini berarti bahwa bidang-bidang fungsional dan berbagai satuan kerja dalam organisasi dapat menjadi sumber data. Sedangkan data eksternal dapat diperoleh dari lingkungan sekitar. Pengumpulan data secara eksternal harus disesuaikan demean kondisi dan kebutuhan organisasi. Seperti yang dijelaskan oleh
Bapak La Pou, S.Pd, selaku Kepala Sekolah bahwa:

"Dalam pengumpulan data harus merencanaan data, menetapkan tujuan, jenis data dan waktu pengumpulan data sampai pada pengamanan data. Data dapat diambil dari seluruh unit kerja dalam organisasi yaitu, dari wakasek bagian kesiswaan, pengajaran, sarana dan prasarana, dan keuangan, sehingga disetiap unit yang memiliki waki-wakil akan menunjang keefektifan pengumpulan data untuk diolah menjadi sebuah informasi yang bermanfaat bagi pengguna infomasi. Misalnya bagian kesiswaan meliputi data riwayat siswa, jenis kelamin, latar belakang orang tua dan sebagainya sedangkan bagian pengajaran meliputi pembuatan program tahunan, semester dan perangkat pembelajaran yang akan dilakukan dalam satu semester, bagian keuangan meliputi perencanaan keuangan, pelaksanaan keuangan (penerimaan dan pengeluaran), sedangkan bagian sarana prasarana meliputi pengadaan sarana prasarana, dan mengkoordinasikan pendayagunaan sarana prasarana sekolah".

Selanjuntya, Kepala Tata Usaha, dalam hal ini Bapak La Ode Mahrum, S.E., menyatakan bahwa:

"Dalam pengumpulan data masih terdapat kesalahan atau kendala yang didapat ketika data yang diinginkan segera dikumpulkan, dari unit kerja terlambat dalam pemberian datanya. Jadi ketika data diinput terkadang kita berungkali mengirimnya."

Jadi, dapat dikatakan bahwa data dapat diperoleh dari berbagai sumber dalam berbagai bentuk. Pada dasarnya data diperoleh pada fakta-fakta yang ada di lapangan. Data yang memiliki makna tertentu bagi pengembangan organisasi, maka data 
1415 Penerapan Sistem Informasi Manajemen Pendidikan dalam Proses Pembelajaran - Siti Hajar Loilatu, M.Rusdi, Musyawir

DOI: https://doi.org/10.31004/basicedu.v4i4.520

akan diklarifikasi dan disusun menjadi informasi. Pada pengumpulan data dapat dikatakan berjalan baik dan normal apabila semua komponen di sekolah atau seluruh unit kerja tepat waktu dalam pemberian data dan saling bekerja sama untuk mencapai tujuan organisasi.

2. Bagian Pengolahan Data

Untuk melakukan pengolahan data tentunya mempunyai prosedur, sebagaimana yang dijelaskan oleh Bapak La Pou, S.Pd., selaku Kepala Sekolah.

"Dalam mengolah data dengan mengikuti serangkaian langkah tertentu sehingga data diubah ke dalam bentuk informasi yang lebih berguna dengan menggunakan perangkat komputer kemudian diinput melalui pengelola data yaitu dapodik. Dengan sistem pengolahan data melalui dapodik maka pengelolaan riwayat data sekolah, peserta didik, pendidik, karyawan sekolah lebih mudah diterintegrasikan dan disimpan secara terpusat dan dapat diakses dengan mudah dalam batasan tertentu melalui internet. Selain itu proses pemutakhiran data dapat dilakukan secara langsung daring (dalam jaringan) dan real time dengan memanfaatkan koneksi internet."

Terkait dengan mengolah data dengan prosedur yang telah ditetapkan harus memastikan prosedur tersebut telah terbebas dari kesalahan meliputi:

a. Koneksi peralatan pendukung untuk mengecek pendeteksian kode.

b. Memastikan bahwa prosesor yang digunakan tidak terdapat kesalahan.

c. Pengecekan terhadap kompabilitas program sebelumnya dengan program baru yang digunakan.

\section{d. Ketersediaan prosedur.}

Untuk melakukan pencegahan kesalahan yang terjadi sehingga perlu disediakan prosedur pencegahan yang memberikan informasi tentang prosedur yang benar kepada operator dalam pengolahan data. Sehubungan dengan hal tersebut, Kepala Tata Usaha dalam hal ini, Bapak La Ode Mahrum, S.E., mengatakan bahwa

"Dalam mengolah data juga harus dilakukan secara berkesenambungan karena dengan perkembangan waktu maka secara otomatis juga akan mengalami perubahan pada data untuk mengantisipasi perubahan data pada unit pengolah data harus selalu memperbarui data sesuai dengan kenyataan".

Seiring dengan perkembangan waktu, secara otomatis fakta yang terjadi juga mengalami perkembangan. Hal ini akan berpengaruh pada data-data yang diperlukan. Untuk mengantisipasi perubahan data yang terjadi setiap waktu, unit pengolah data harus mengikuti dan meng-up date data sesuai dengan kenyataan, karena hal ini akan mempengaruhi informasi yang diterima manajer (kepala sekolah dan wakil-wakilnya) dan akan berdampak besar pada perkembangan organisasi.

Dengan demikian dapat disimpulkan bahwa pengolahan data dilakukan secara langsung online dan real time dengan memanfaatkan koneksi internet dan pengolahan data harus dilakukan secara terus menerus dan berkesinambungan dimana unit pengolah data harus mengikuti dan meng-up date data sesuai dengan kenyataan karena hal 
1416 Penerapan Sistem Informasi Manajemen Pendidikan dalam Proses Pembelajaran - Siti Hajar Loilatu, M.Rusdi, Musyawir

DOI: https://doi.org/10.31004/basicedu.v4i4.520

ini akan mempengaruhi informasi yang diterima manajer (kepala sekolah dan wakilwakilnya) dan akan berdampak besar pada perkembangan organisasi.

3. Bagian Penyimpanan Data

Penyimpanan data sangat diperlukan, karena tujuan utamanya adalah demi keamanan data. Apabila level-level manajemen membutuhkan data, baik data berupa bahan mentah maupun data yang telah diolah, maka data dapat diambil dan digunakan sesuai dengan kebutuhan manajer (kepala sekolah dan wakil-wakilnya). Penyimpanan informasi sangat penting karena tidak semua informasi yang dimiliki digunakan saat sekarang tetapi sesuai dengan kebutuhan.

Menurut Bapak La Pou, S.Pd., selaku Kepala Sekolah bahwa:

"Untuk menjaga validitas data sekolah, siswa, pendidik dan karyawan, pada sistem dapodik maka diterapkan sistem penomoran khusus yang berfungsi sebagai identitas tunggal yang berlaku seumur hidup dalam skala nasional. Sistem penomoran tersebut menjadi kunci utama Dan demi keamanan data dari sistem dapodik. Maka terdapat tiga subprogram pada dapodik yaitu, NPSN (Nomor Pokok Sekolah Nasional), NISN (Nomor Induk Siswa Nasional), dan NIGN (Nomor Induk Guru Nasional)”.

Nomor Induk Siswa Nasional (NISN) adalah kode pengenal siswa yang bersifat tunggal dan berlaku seumur hidup membedaka satu siswa dengan siswa lainnya. Penerapan kode pengenal siswa disetiap sekolah pada sistem dapodik dapat terjaga validitasnya. Nomor Pokok Sekolah Nasional
(NPSN) merupakan kode pengenal sekolah yang bersifat tunggal dan berlaku selama sekolah tersebut aktif.

Kode terbaru ini disiapkan untuk menggantikan NSS (Nomor Statistik Sekolah) yang dinilai sudah konsisten dan sangat rentang terhadap perubahan wilayah/daerah Indonesia. NPSN seluruh angka demean jumlah 10 digit sehingga mudah dihafal atau dituliskan. Nomor Induk Guru Nasional (NIGN) adalah kode pengenal guru/karyawan yang berlaku seumur hidup. Penerapan kode pengenal guru/karyawan yang berlaku secara nasional, maka data guru/karyawan pada sistem dapodik terjaga validitasnya. Pada implementasinya, melalui pengolah data dapodik, sekolah diberikan tanggung jawab dalam mengumpulkan data siswa, sekolah, dan guru/karyawan dan mengoperasikan sistem dapodik yang telah disediakan dan melaporkan hasil kerja masing-masing.

Untuk menjaga keberlanjutan data siswa, sekolah, guru, dan karyawan yang valid pada dapodik maka perlu dioptimalkan penggunaan NISN, NPSN dan NIGN sebagai salah satu syarat utama dalam pelaksanaan program kegiatan di depdiknas, meliputi: Bantuan Operasional Sekolah (BOS), Nomor Ujian di sekolah atau tingkat nasional, statistik pendidikan, dan sertifikat guru. Selanjunya, Kepala Tata Usaha dalam hal ini, Bapak La Ode Mahrum, S.E., Menyatakan bahwa:

"Kegiatan penyimpanan informasi sangat penting agar terjamin keamanannya, hemat biaya, serta mudah dicari dan diambil apabila diperlukan sewaktu-waktu. Selain dalam ingatan manusia, penyimpanan informasi dapat 
1417 Penerapan Sistem Informasi Manajemen Pendidikan dalam Proses Pembelajaran - Siti Hajar Loilatu, M.Rusdi, Musyawir

DOI: https://doi.org/10.31004/basicedu.v4i4.520

dilakukan pada alat-alat seperti hardisk, flashdisk, dan sebagainya."

Jadi, dapat disimpulkan bahwa informasi yang telah terkumpul dan terolah dengan baik perlu disimpan dengan sebaik mungkin mengingat informasi sebagai salah satu sumber daya strategis dalam organisasi, maka penerapan kode dilakukan agar terjaga validitas data tersebut.

Untuk menjalankan suatu organisasi, tentu diberikan amanah dan tanggung jawab kepada seseorang agar suatu organisasi berjalan sesuai dengan tahapan-tahapan yang sudah direncanakan sebelumnya. Hal itu, menurut Kepala Tata Usaha Bapak La Ode Mahrum, S.Pd., M.Pd. menyatakan bahwa:

"Yang bertindak sebagai pelaksana sistem informasi manajemen adala Wakil Kepala Sekolah yang terdiri dari empat personil seperti Wakasek bagian pengajaran, kesiswaan, sarana dan prasarana, dan humas yang dibagi misalnya dari kesiswaan yaitu dari seluruh siswa diinput datanya mulai dari data riwayat pendidikan, status keluarga kemudian semua itu dimasukkan dalam sebuah sistem dapodik yang dikoordinir oleh operator sekolah."

Jadi dapat disimpulkan bahwa, yang bertindak sebagai ketua sistem informasi manajemen adalah Kepala Sekolah sekaligus penaggung jawab, dan yang bertindak sebagai pelaksana sistem informasi manajemen adalah Wakil Kepala Sekolah yang terdiri dari empat personil seperti Wakasek bagian pengajaran, kesiswaan, sarana prasarana dan humas.

Umumnya di dunia pendidikan penggunaan dan pengelolaan sistem informasi manajemen pendidikan tidak dapat dipisahkan dari aktivitas pendidikan itu sendiri. Kedua bidang ini saling membutuhkan satu sama lain. Dalam menggambarkan hubungan kedua aspek tersebut manajemen menilai pendidikan sebagai penggerak pada sistem informasi manajemen pendidikan sekaligus system informasi pendidikan sebagai penentu proses manajemen pendidikan.

Hal ini terjadi di SMP Negeri 9 Kabupaten Buru bahwa, sistem informasi manajemen sangat berperan dalam dunia pendidikan khususnya dalam proses belajar mengajar di SMP Negeri 21 Makassar. Sebagaimana yang di jelaskan oleh Bapak, La Ode Mahrum, S.E., selaku Kepala Tata Usaha.

"Dengan diterapkan sistem informasi
manajemen di sekolah, dapat dijadikan
sebagai salah satu dasar dalam
meningkatkan mutu pendidikan dimana
dalam memberikan kesempatan kepada
guru dan pengurus sekolah untuk
meningkatkan kualitas komunikasi dan
pembinaan kepada siswa. Siswa juga akan
lebih mengembangkan kepribadian dan
pengetahuannya. Misalnya penggunaan
teknologi dengan memfasilitasi praktek
pembelajaran dengan memadukan komputer
dengan penggunaan wifi atau jaringan
internet. Jadi, ketika dalam proses belajar
mengajar akan menciptakan suasana yang
efektif, mereka dapat dengn mudah
mengerjakan tugas, dalam proses belajar
mengajar tidak membosankan, siswa lebih
aktif dan semangat belajarnya".

Berdasarkan semua pernyataan informan di atas, maka peneliti dapat menarik kesimpulan bahwa penerapan sistem informasi manajemen pada lembaga pendidikan sangat dibutuhkan, karena dalam menghadapi persaingan global lembaga pendidikan dituntut untuk memberikan informasi lebih cepat, akurat dan nyaman yang 
1418 Penerapan Sistem Informasi Manajemen Pendidikan dalam Proses Pembelajaran - Siti Hajar Loilatu, M.Rusdi, Musyawir

DOI: https://doi.org/10.31004/basicedu.v4i4.520

merupakan bagian dari kualitas pelayanan, sehingga akan menjadi keunggulan bersaing.

\section{Pelaksanaan Proses Pembelajaran di SMP}

\section{Negeri 9 Kabupaten Buru}

Berikut penulis akan memberikan penjelasan mengenai pelaksanaan proses pembelajaran di SMP Negeri 9 Kabupaten Buru. Akan tetapi sebelum kita membahas lebih lanjut mengenai pelaksanaan proses pembelajaran di SMP Negeri 9 Kabupaten Buru berikut sedikit penjelasan mengenai proses pembelajaran. Proses pembelajaran merupakan proses interaksi peserta didik dengan pendidik dan sumber belajar pada suatu lingkungan belajar yang meliputi pendidik dan peserta didik yang saling bertukar informasi. Pendidik sangat berperan dalam membantu perkembangan peserta didik untuk mewujudkan tujuan hidupnya secara optimal.

Pendidik dalam proses pembelajaran memiliki peran yang sangat penting bagaimana pun hebatnya kemajuan sains dan teknologi, peran pendidik akan tetap diperlukan. Untuk melaksanakana proses pembelajaran, mempunyai tiga tahapan dalam proses pembelajaran yaitu: tahapa perencanaan, tahap pelaksana, dan tahap evaluasi.

\section{Tahap Perencanaan}

Kegiatan perencanaan yang baik senantiasa berawal dari rencana yang matang. Perencanaan yang matang akan menunjukkan hasil yang optimal dalampembelajaran. Perencanaan merupakan proses penyusunan sesuatu yang akan dilaksanakan untuk mencapai tujuan yang telah ditentukan. Dalam hal ini sebelum melaksanakan proses pembelajaran di SMP Negeri 9 Kabupaten Buru, terlebih dahulu harus mempunyai perencanaan/persiapan.

Sebagaimana yang telah dijelaskan oleh Bapak Awaluddin Papalia, S.Pd selaku wakasek bidang kurikulum.

"Sebelum melaksanakan proses pembelajaran harus mempunyai kesiapan yaitu: pertama, Analisis hari efektif dan analisis program pembelajaran. Untuk mengawali kegiatan penyusunan program pembelajaran, guru perlu membuat analisis hari efektif selama selama satu semester. Dari hasil analisis hari efektif akan diketahui jumlah hari efektif dan hari libur tiap pekan atau tiap bulan sehingga memudahkan penyusunan program pembelajaran selama satu semester. Dasar pembuatan analisis hari efektif adalah kalender pendidikan dan kalender umum. Berdasarkan analisis hari efektif tersebut dapat disusun analisis program pembelajaran. Kedua, membuat program tahunan, dan program semester. Yang dimaksud dengan program tahunan yaitu, penyusunan program pembelajaran selama tahun pelajaran dimaksudkan agar keutuhan dan kesinambungan program pembelajaran atau topik pembelajaran yang akan dilaksanakan dalam dua semester tetap terjaga. Program semester yaitu, penyusunan program semester didasarkan pada hasil analisis hari efektif dan program pembelajaran tahunan. Ketiga, menyusun silabus. yang dimaksud dengn silabus yaitu, penjabaran dari standar kompetensi, kompetensi dasar yang ingin dicapai, dan pokok-pokok serta uraian materi yang perlu dipelajari siswa dalam rangka mencapai standar kompetensi dan kompetensi dasar. Keempat, Menyusun Rencana Proses Pembelajaran (RPP). RPP disusun guru sebelum melakukan proses pembelajaran. RPP bersifat khusus dan kondisional, dimana setiap sekolah tidak sama kondisi siswa dan sarana prasarana sumber belajarnya. Karena itu, penyusunan RPP didasarkan pada silabus dan kondisi pembelajaran agar kegiatan pembelajaran dapatberlangsung sesuai harapan. Kelima, Penilaian Pembelajaran, yang dimaksud 
1419 Penerapan Sistem Informasi Manajemen Pendidikan dalam Proses Pembelajaran - Siti Hajar Loilatu, M.Rusdi, Musyawir

DOI: https://doi.org/10.31004/basicedu.v4i4.520

penilaian pembelajaran yaitu, proses yang harus dilakukan guru dalam rangkaian kegiatan pembelajaran. Prinsip penilaian antara lain valid, mendidik berorientasi pada kompetensi, adil, objektif, terbuka, dan berkesenambungan".

Selanjutnya, hal tersebut juga dijelaskan oleh guru bidang studi, dalam hal ini Ibu Nurbaya Umasugi, S.Pd bahwa

"Sebelum melakukan pembelajaran, pendidik terlebih dahulu menyampaikan tujuan dan indikator-indikator yang akan dicapai pada setiap pertemuan pembelajaran, dengan menggunakan teknologi informasi dan media pembelajaran yaitu berupa komputer dan $L C D^{\prime \prime}$.

Jadi, dapat disimpulkan bahwa, sebelum melaksanakan proses pembelajaran terlebih dahulu menyiapkan segala sesuatu yang diperlukan dalam proses pembelajaran seperti, menganalisi hari efektif dan analisis program pembelajaran, membuat program tahunan dan program semester, menyusun silabus, menyusun RPP, dan membuat penilaian pembelajaran. Kemudian sebelum menyampaikan materi/informasi terlebih dahulu menyampaikan tujuan pembelajan dan indikatorindikator pembelajaran yang akan dicapai.

\section{Tahap Pelaksanaan}

Tahap ini merupakan tahap implementasi atau tahap perencanaan atas desain perencanaan yang telah dibuat guru. Dalam tahap ini, guru melakukan interaksi belajar mengajar melalui penerapan berbagai strategi metode dan teknik pembelajaran, serta pemanfaatan seperangkat media. Seperti yang dijelaskan oleh Bapak Awaluddin Papalia, S.Pd., selaku Wakasek Kurikulum bahwa:
"Dalam tahap pelaksanaan pembelajaran ada beberapa hal yang perludiperhatikan guru yaitu, pertama, Aspek Pendekatan dalam Pembelajaran. Pendekatan ini berupa pendekatan pembelajaran pemrosesan informasi, yaitu membantu siswa untuk memproses informasi yang diperoleh, pendekatan pembelajaran individu yaitu, membantu siswa mengembangkan pribadi agar lebih produktif terhadap situasi dan lingkungan. Kedua, Aspek Strategi dan Taktik dalam Pembelajaran. Strategi pembelajaran yaitu, tindakan pembelajaran yang dilakukan guru yang dinilai strategis untuk mengaktualisasikan proses pembelajaran. Terkait dengan pelaksanaan strategi adalah taktik pembelajaran. Taktik pembelajaran berhungan dengan tindakan teknis untuk menjalankan strategi. Untuk melaksanakan strategi diperlukan kiat-kiat teknis, agar nilai strategis setiap aktivitas yang dilakukan guru, murid di kelas dapat terealissi. Ketiga, Aspek Metode dan Teknik dalam Pembelajaran. Metode merupakan bagian dari sejumlah tindakan strategis yang menyangkut tentang cara, bagaimana interaksi pembelajaran dilakukan. Metode yang digunakan dalam proses pembelajaran yaitu, metode ceramah, berdiskusi, bekerja kelompok, bersimulasi, dan sebagainya. Dan media pembelajaran yang digunakan yaitu, media cetak (buku), gambar, LCD dan komputer."

Hal ini pula dijelaskan oleh Ibu Ratnawati Umaternate, S.Pd selaku guru bidang studi bahwa:

"Untuk mengembangkan potensi peserta didik, peserta didik membuat kelompok belajar yang diarahkan langsung oleh guru mata pelajaran dengan menggunakan media pembelajaran berupa komputer dan LCD, peserta didik mencari matari yang mereka butuhkan kemudian mendiskusikannya atau memecahkan masalah yang tidak dipahami dengan teman kelompok lainnya."

Pendidik juga harus mampu memahami dan memberikan solusi atas segala kesulitan yang dihadapi peserta didik dalam proses pembelajaran. Untuk itu pendidik dituntut untuk mengenal 
1420 Penerapan Sistem Informasi Manajemen Pendidikan dalam Proses Pembelajaran - Siti Hajar Loilatu, M.Rusdi, Musyawir

DOI: https://doi.org/10.31004/basicedu.v4i4.520

peserta didiknya. Sebagaimana yang dijelaskan oleh Ibu Nurbaya Umasugi, S.Pd. bahwa:

"Apabila peserta didik mendapat kesulitan dalam pembelajara, maka guru mata pelajaran membimbing peserta didik dengan menggunakan media pembelajaran untuk memaparkan pelajaran dan mempraktikkan agar dengan mudah peserta didik memahami apa yang dijelasksen pendidik."

Jadi dapat disimpulkan bahwa dalam tahap pelaksanaan proses pembelajaran yaitu, menggunakan aspek pendekatan, menggunakan aspek strategi dan taktik dalam proses pembelajaran, menggunakan metode dan teknik dalam proses pembelajaran. Metode yang digunakan dalam proses pembelajaran yaitu, ceramah, berdiskusi, berkelompok, bersimulasi, dan sebagainya. Media yang digunakan dalam proses pembelajaran yaitu, media cetak (buku), gambar, LCD, dan komputer.

\section{Tahap Evaluasi}

Pada tahap evaluasi, kegiatan guru adalah melakukan penilaian atas proses pembelajaran yang telah dilakukan. Evaluasi adalah alat untuk mengukur ketercapaian tujuan. Dengan evaluasi, dapat diukur kuantitas dan kualitas pencapaian tujuan pembelajaran. Dalam hal ini dijelaskan oleh Bapak Awaluddin Papalia, S.Pd., selaku Wakasek Kurikulum, bahwa:

"Evaluasi pengetahuan belajar dapat dilakukan dengan ujian tulis, lisan, dan daftar ujian pertanyaan. Evaluasi belajar keterampilan, dapat dilakukan dengan ujian praktek, analisis keterampilan dan analisis tugas serta evaluasi oleh peserta didik sendiri. Evaluasi belajar sikap dapat dilakukan dengan daftar sikap isian, daftar isian sikap yang disesuaikan dengan tujuan program, dan skala deferensial sematik."
Dijelaskan pula oleh Ibu Ratnawati Umaternate, S.Pd. bahwa:

“Apapun bentuk tes yang diberikan kepada peserta didik, tetap harus sesuai dengan persyaratan yang baku, yakni tes itu harus: Memeiliki validitas yaitu, mengukur atau menilai apa yang hendak diukur atau dinilai, terutama menyangkut kompetensi dasar dan materi standar yang telah dikaji. Mempunyai reliabilitas yaitu, ketetapan hasil yang diperoleh peserta didik, bila dites kembali dengan tes yang sama. Pelaksanaan evaluasi harus efesien dan praktis."

Jadi dapat disimpulkan bahwa dalam melaksanakan tahap evaluasi, yang perlu dievaluasi oleh pendidik yaitu, pengetahuan belajar yang dites dengan secara tertulis, lisan, dan daftar pertanyaan ujian. Evaluasi belajar keterampilan yang dievaluasi dengan ujian praktek, dan analisis tugas yang dievaluasi sendiri oleh pendidik. Dan bentuk tes yang diberikan kepada peserta didik tetap harus dengan persyaratan yang baku. Keberadaan teknologi informasi sangat membantu dalam pelaksanaan proses belajar mengajar. Mempermudah pendidik dalam menyampaikan informasi, dan mempermudah dalam mencari bahan ajar.

Sebagaimana dijelaskan oleh Ibu Ratnawati Umaternate, S.Pd selaku guru bidang studi bahwa:

"Teknologi informasi sangat mendukung dalam proses belajar mengajar, karena membantu pendidik menyampaikan informasi dengn menggunakan media pembelajaran seperti $L C D$ dan komputer, teknologi informasi juga membantu pendidik dan peserta didik dalam mencari bahan ajar untuk memperlancar proses belajar mengajar." 
1421 Penerapan Sistem Informasi Manajemen Pendidikan dalam Proses Pembelajaran - Siti Hajar Loilatu, M.Rusdi, Musyawir

DOI: https://doi.org/10.31004/basicedu.v4i4.520

Jadi, dapat disimpulkan bahwa, pelaksanaan proses pembelajaran adalah interaksi peserta didik dengan pendidik dan sumber belajar pada suatu lingkungan belajar yang meliputi pendidik dan peserta didik yang saling bertukar informasi yang menggunakan media pembelajaran berupa, media cetak (buku), gambar, LCD, computer, dan sebagainya. Dan memanfaatkan teknologi informasi untuk menyampaikan informasi dan mencari bahan ajar untuk memperlancar proses pembelajaran.

\section{Faktor Yang Menghambat Dan Mendukung Penerapan Sistem Informasi Manajemen Dalam Proses Pembelajaran Di SMP Negeri 9 Kabupaten Buru.}

Pada penerapan sistem informasi manajemen di SMP Negeri 9 Kabupaten Buru ada beberapa faktor yang menghambat dan mendukung dengan adanya sistem informasi manajemen. Sebagaimana yang dijelaskan oleh Bapak La Ode Mahrum selaku kepala Tata Usaha pernyataanya bahwa

"Faktor yang menunjang sistem informasi manajemen yaitu, dengan adanya sistem dapodik yang melakukan pendataan tentang data pendidik, peserta didik, dan karyawan. Kemudian faktor yang menghambat sistem informasi manajemen yaitu, kesalahan dan keterlambatan pemberian data dari tiaptiap unit kerja".

Jadi, dapat disimpulkan bahwa faktor yang menunjang dan menghambat penerapan sistem informasi manajemen di SMP Negeri 9 Kabupaten Buru, yaitu dengan adanya sistem dapodik dan adanya kesalahan dan keterlambatan pemberian data dari tiap-tiap unit kerja.

\section{SIMPULAN}

Berdasarkan data-data yang dikumpulkan dan dijelaskan pada bagian sebelumnya peneliti dapat memperoleh kesimpulan sebagai berikut:

1. Penerapan sistem informasi manajemen sangat penting di lembaga pendidikan khususnya di SMP Negeri 9 Kabupaten Buru, dengan menggunakan aplikasi pengolah data yaitu dapodik dan teknologi informasi dalam mendukug proses pembelajaran memberikan layanan pendidikan dengan menfasilitasi praktek pembelajaran dengan menggunakan infrakstruktur teknologi, seperti fasilitas belajar dengan memadukan komputer.

2. Pelaksanaan proses pembelajaran di SMP Negeri 9 Kabupaten Buru berdasarkan hasil penelitian yaitu, sebelum melaksanakan proses pembelajaran harus melalui tiga tahap yaitu, pertama, tahap perencanaan. Dalam tahap ini membuat analisis hari efektif dan analisis program pembelajaran, membuat program tahunan, menyusun silabus, menyusun RPP, dan membuat penilaian pembelajaran. Kedua, tahap pelaksanaan. Dalam tahap ini yang perlu dilakukan yaitu, aspek pendekatan dalam pembelajaran, aspek stretegi dan taktik dalam pembelajaran, aspek metode dan teknik dalam pembelajaran. Media pembelajaran yang dipakai dalam proses pembelajaran yaitu, media cetak (buku), gambar, LCD dan computer. Ketiga, tahap evaluasi. Dalam tahap ini yang dievaluasi yaitu, pengetahuan belajar yangdites dengan secara tertulis, lisan, dan daftar pertanyaan ujian. 
1422 Penerapan Sistem Informasi Manajemen Pendidikan dalam Proses Pembelajaran - Siti Hajar Loilatu, M.Rusdi, Musyawir

DOI: https://doi.org/10.31004/basicedu.v4i4.520

3. Evaluasi belajar keterampilan yang dievaluasi dengan ujian praktek, dan analisistugas yang dievaluasi sendiri oleh pendidik dan bentuk tes yang diberikan kepada peserta didik tetap harus dengan persyaratan yang baku.

\section{DAFTAR PUSTAKA}

Helmawati. 2015. Sistem Informasi Manajemen. Bandung: PT Remaja Rosdakarya Offset.

Moleng J., Lexy. 2013. Metode Penelitian Kualitatif. Bandung: Remadja Rosdakarya.

Salehuddin. 2012. Perencanaan Pembelajaran. Jakarta: PT Bumi Aksara.

Siswanto H. B. 2012. Pengantar Manajemen. jakarta: Bumi Aksara.

Subagyo, Joko. 2012. Metode Penelitian dalam Teori dan Praktik. Jakarta: Rineka Cipta.

Sudjana, Nana. 2014. Teknologi Pengajaran. Bandung: Sinar Baru.

Surahmad, Winarno. 2013. Pengantar Penelitian Ilmiah Metode dan Teknik. Bandung: Tarsito.

Sutabri, Tata. 2013. Sistem Informasi Manajemen.Yogyakarta: Andi.

Pidarta, Made. 2013. Sistem Informasi Manajemen. Jakarta: Mitra Wacana Media.

Wahyudi \& Subando. 2012. Pengantar Manajemen. Jakarta: Bumi Aksara.

Zakiyudin, Ais. 2012. Sistem Informasi Manajemen. Jakarta: Mitra Wacana Media. 